\title{
Safety, Efficacy, and Preventive Role of Subcutaneous and Sublingual Allergen Immunotherapy for the Treatment of Pediatric Asthma
}

This article was published in the following Dove Press journal: Journal of Asthma and Allergy

\author{
Arianna Giannetti ${ }^{1}$ \\ Giampaolo Ricci (ID) \\ Michela Procaccianti ${ }^{2}$ \\ Angelica Santoro ${ }^{2}$ \\ Carlo Caffarelli $\mathbb{D}^{2}$ \\ 'Pediatric Unit, Department of Medical \\ and Surgical Sciences, University of \\ Bologna, Bologna, Italy; ${ }^{2}$ Clinica \\ Pediatrica, Department of Medicine and \\ Surgery, University of Parma, Parma, Italy
}

\begin{abstract}
Allergen-specific immunotherapy is currently the only treatment with the potential to modify and prevent progression of allergic asthma in children. In clinical practice, it is available in two forms: subcutaneous immunotherapy and sublingual immunotherapy. Trials and meta-analyses showed both the safety and the short- and long-term benefits of allergenspecific immunotherapy in asthmatic children. However, its use and role in asthma remains controversial, since studies are largely heterogeneous. This is mainly due to the lack of consensus on the optimal primary outcome to be considered for clinical trials evaluating the efficacy of allergen-specific immunotherapy in asthma. Therefore, well-conducted researchis needed using standardized and validated tools to evaluate key outcomes in asthmatic children.
\end{abstract}

Keywords: asthma, allergen-specific immunotherapy, children, allergy, grass, house dust mite

\section{Introduction}

Asthma is a serious global health problem affecting over 300 million people worldwide. ${ }^{1}$ The prevalence is increasing in many countries, especially among children, and represents one of the leading causes for hospitalizations. ${ }^{2}$

GINA recommendation defines asthma as a heterogeneous disease usually characterized by chronic airway inflammation that is characterized by wheeze, dyspnea, chest tightness, and/or cough with obstruction of low airways. ${ }^{1}$ At present, the term asthma is considered an umbrella diagnosis for several diseases with distinct mechanistic pathways (endotypes) and variable clinical presentations (phenotypes). ${ }^{3}$ The precise definition of these endo-phenotypes is crucial for the therapeutic asthma management and for the prognosis.

In about $75 \%$ of all children with asthma, atopy is present. ${ }^{1}$ Allergic asthma is probably the most common asthma phenotype ${ }^{4}$ (high Th2) characterized by high $\operatorname{IgE}$ eosinophil inflammation and bronchial hyperreactivity. The presence of past and/or family history of allergic disease such as eczema, allergic rhinitis (AR) is common, and it often begins in childhood. ${ }^{1}$ Currently asthma drugs can effectively control symptoms and the ongoing inflammatory process, but they do not affect the underlying immune response.

When inhaled corticosteroids were suspended, the relative risk for asthma exacerbations was shown to be $2.35(1.88-2.92)$ in comparison with those who
Correspondence: Carlo Caffarelli Clinica Pediatrica, Dipartimento d Medicina e Chirurgia, Azienda

Ospedaliera-Universitaria, University of

Parma, Parma, Italy

Tel +390521702207

Fax +390521702807

Email carlo.caffarelli@gmail.com 
did not suspend, and 55\% of the subjects did not succeedin halting treatment with inhaled corticosteroids/long-acting beta agonists. ${ }^{5}$ Asthmatic symptoms can be induced by several allergens ${ }^{1,6-9}$ including pollens, house dust mites (HDM), molds, furred animals, venom, drugs, and foods.

Allergen-specific immunotherapy (AIT) with one or multiple inhalant allergens currently represents the only causal treatment that can modify the natural history of allergic respiratory diseases. ${ }^{8,9}$ It is also used in other allergic diseases such as hymenoptera venom hypersensitivity, ${ }^{9}$ and AIT trials are ongoing for atopic dermatitis ${ }^{10}$ and food allergy. $^{11}$

AIT for aeroallergens consists of the administration of standardized allergen extracts to patients with respiratory IgE-mediated diseases (AR, allergic asthma) to the same allergen to achieve immune tolerance and prevent the onset of symptoms. AIT is mainly used in two forms: subcutaneous immunotherapy (SCIT) and sublingual immunotherapy (SLIT). Despite the first treatment with SCIT which has been reported at the beginning of the past century, ${ }^{12}$ the first randomized study on SLIT was performed in $1986 .{ }^{13,14}$ SCIT is based on regular subcutaneous administration of allergen extract, that is available in either aqueous, physically adsorbed (depot), or chemically modified (allergoids) allergens. SLIT consists in putting under the tongue the extract contained in an aqueous solution as drops or in tablets and then swallowing. There is no international regulation on AIT. SLIT tablets for grass pollen, ragweed, Japanese cedar, and $\mathrm{HDM}^{15}$ have been registered for children, adolescents, and adults. The other AIT products are available as "Patient Name Products". ${ }^{16}$ Asthma guidelines do not provide clear recommendations about AIT use in asthmatic children, and their role in this disease remains controversial. This is mainly due to the scarce clinical trials evaluating relevant asthma outcomes as primary variables, because the AIT effect may only be evident following a long treatment period $^{17}$ and for other factors such as the risk of adverse reactions, the heterogeneity of allergen compounds, and commercial products. ${ }^{18,19}$ There is a need for biomarkers of efficacy, safety, compliance, and immune monitoring in AIT trials. $^{20}$

Recently, the Global Initiative for Asthma (GINA) recommendation states that AIT may be an option for adults with AR who are sensitized to HDM, with suboptimal controlled asthma despite low high dose inhaled corticosteroid, providing forced expiratory volume in the 1st second $\left(\mathrm{FEV}_{1}\right)$ is $>70 \%$ predicted. However, potential benefits must be weighed against the risk of adverse effects, and the inconvenience and the cost to the patient and health system. ${ }^{1}$

The aim of our review is to assess the use of AIT in childhood asthma, focusing on the most relevant aspects of efficacy and safety.

\section{Immune Modulation of AIT}

AIT effect (Figure 1) seems to be linked to modification of the function of monocytes, B-cells, and T-cells, as well as basophils, eosinophils, and mast cells count. ${ }^{21-23}$ It has been shown that mediators of anaphylaxis (histamine and leukotrienes) are released during AIT without inducing a systemic anaphylactic response. ${ }^{24}$ This is in agreement with findings of lower mediator release from mast cells and basophils ${ }^{24,25}$ as a result of induction not only of IgG4 but also IgG2 and IgG3 that suppress FceRI-mediated responsiveness, following the start of AIT. ${ }^{26}$

Studies on cellular immunity has been mainly conducted in adults and there are some data that similar mechanisms occur in children. ${ }^{9}$ Th 2 cells have been considered as the main source of type 2 cytokines; the imbalance of Th1/Th2 is the key to the appearance of asthma. Furthermore, the immune responses of Th17 and T-regulatory cells (Treg) also play an important role. Th17 cell response increases, and Treg expression decreases in asthma. The severity and symptom control of asthma are closely related to the imbalance of Th17/Treg. It is believed that regulating Th1/Th2 and Th17/Treg immune balance may be the key to asthma treatment. $^{27}$

Dendritic cells play an important role in SLIT since there is a massive exposure to the culprit allergen. The action of AIT on dendritic cells ${ }^{9}$ leads to an increase in natural regulatory T-cells (nTregs) and induced regulatory T-cells (iTregs) production by the release of IL-12, IL-27, and IL10. Specific Tregs and B-regulatory cells can modify the immune response from allergic Th2 to Th1 response. Moreover, Tregs downregulate mucosal mast cells, basophils, and eosinophils count and function. ${ }^{28}$ Regarding the humoral immunity, AIT through Treg cells enhances specific IgG4 and diminished specific IgE to allergens. Furthermore, Tregs increase IgA that may block Ig receptors together with the specific $\mathrm{IgG} 4{ }^{29}$

\section{Safety}

AIT is contraindicated in patients with medical conditions that increase the risk of treatment-related severe systemic reactions, such as those with significant cardiovascular 

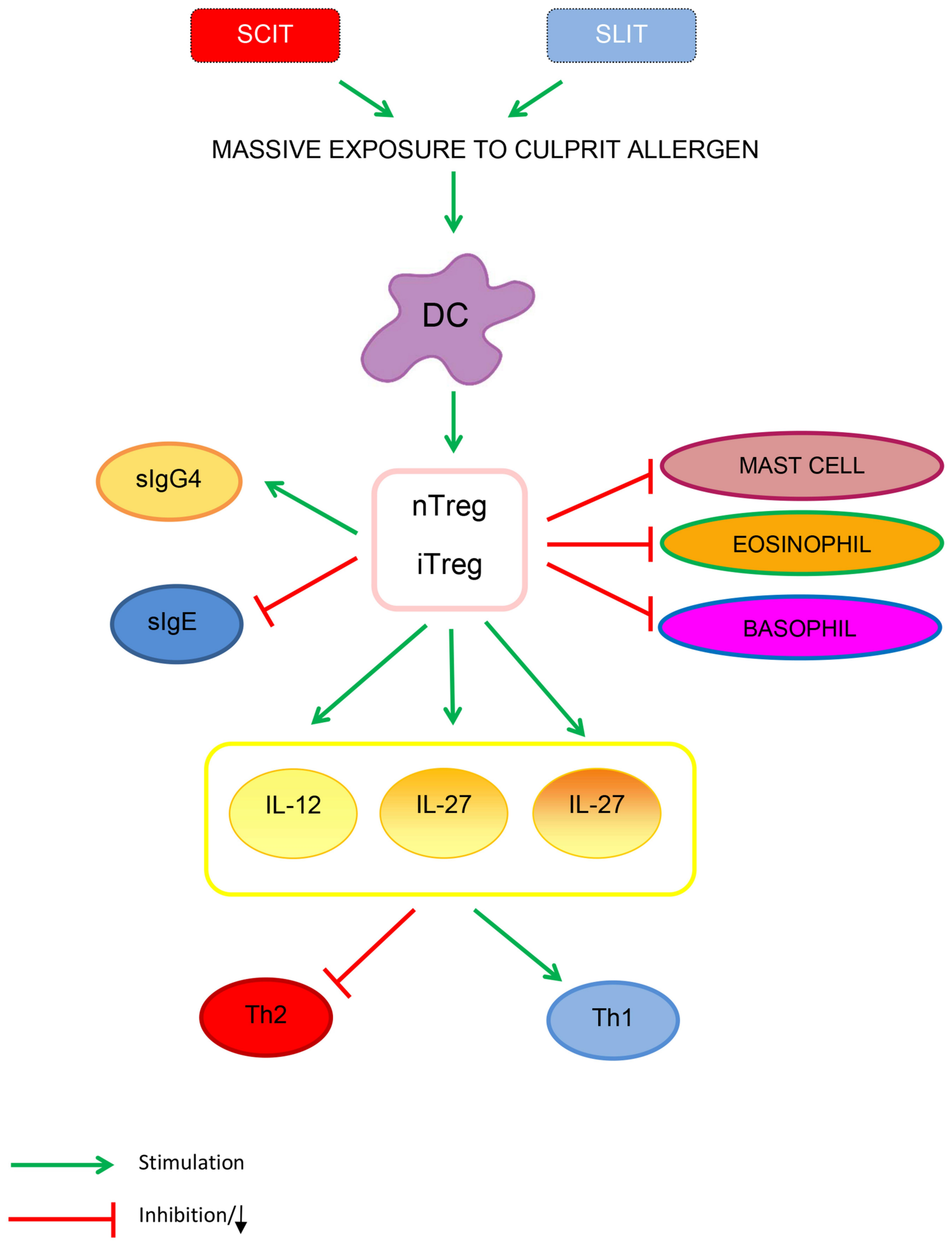

Figure I Immune modulation of AIT. The action of AIT on dendritic cells leads to an increased nTregs and iTregs production by the release of IL-I2, IL-I0, and IL-27. Specific Tregs and B-regulatory cells can modify the immune response from allergic Th2 to ThI response. Moreover, Tregs downregulate count and function of mucosal mast cells, basophils and eosinophils. AIT through Treg cells enhances specific lgG4 and diminished specific lgE to allergens.

Abbreviations: SCIT, subcutaneous immunotherapy; SLIT, sublingual immunotherapy; DC, dendritic cells; nTreg, natural regulatory T-cells; iTreg, induced regulatory T-cells.

diseases (eg, unstable angina, recent myocardial infarction, arrhythmia, and uncontrolled hypertension). Severe or uncontrolled asthma or $\mathrm{FEV}_{1}<80 \%$ are the major independent risk factors for both nonfatal and fatal adverse reactions and, thus, a major contraindication for both SLIT and SCIT. $^{30-32}$ Neoplasms, chronic diseases, and 
autoimmune disorders should also be considered. ${ }^{33}$ AIT should be administered with caution to patients receiving $\beta$-blockers or angiotensin-converting enzyme inhibitors. ${ }^{30}$ Chronic and acute nasal or conjunctival inflammatory responses and nasal polyps are not a contraindication for AIT. $^{34}$

\section{SCIT Safety}

Injections must be performed by trained personnel staff in clinical settings with equipment to manage any possible systemic adverse reactions or anaphylaxis. The patients' general status should be assessed before each injection to reduce the risk of anaphylaxis. ${ }^{30}$ Injection should be postponed in children with febrile illness or bronchospasm. All patients undergoing SCIT should be observed for at least 30 minutes after injection to ensure proper management of systemic adverse reactions. ${ }^{30}$ Adverse events are more frequent when rush build-up schedules are used. ${ }^{35}$ Uncontrolled asthma and human errors were the most common causes of SCIT-induced adverse events. ${ }^{36}$ Adverse reactions to SCIT range from local site reactions, to systemic reactions, such as urticaria-angioedema, anaphylaxis. They have been classified in a grading system. ${ }^{37}$ Local reactions are frequent, in $26-86 \%$ of SCIT injections, but are often well-tolerated. ${ }^{38}$ A systematic review ${ }^{39}$ found that anaphylaxis in asthmatic children receiving SCIT occurred in two of 232 patients, even though systemic reactions are rare when AIT is performed according to safety recommendations. One death was reproted. ${ }^{39}$ Unspecified systemic reactions were also reported in $23 \%$ of children treated with SCIT in non-RCTs. Other reactions, including hives, wheezing, rhinorrhea, asthma, and congestion were also reported in non-RCTs. ${ }^{39}$ Recently, Lee et $\mathrm{al}^{40}$ found that $24 \%$ of patients experienced adverse reactions to SCIT and only one case of anaphylaxis developed. A multicenter study demonstrated that systemic reactions were slightly more frequent in patients with rhinitis with asthma than in those with isolated rhinitis. ${ }^{41}$ Overall, there is insufficient evidence to draw conclusions on the rate of anaphylaxis or fatalities due to SCIT in asthmatic children.

\section{SLIT Safety}

The SLIT-related systemic reaction rate is significantly lower compared with SCIT-related. No fatality has been reported until now, and only a few cases of suspected anaphylaxis have been described, none directly related to pre-existing asthma or to worsening of asthma. ${ }^{32}$ Two of three reports of anaphylaxis to SLIT were in patients who received multiple allergen therapy ${ }^{42,43}$ This suggests that SLIT with multiple allergens poses higher risk for systemic adverse effects. ${ }^{44}$ A comprehensive review ${ }^{45}$ of 104 SLIT studies showed 1.4 serious adverse events per 100,000 SLIT administered doses.

Randomized controlled trials showed that local reactions (pruritus or dysesthesia at the oral cavity, swelling of the oral mucosa, throat irritation) to SLIT are common (up to $80 \%$ of patients). These reactions mirror those elicited in the pollen-food syndrome. ${ }^{46}$ They usually appear at the beginning of SLIT, are mostly mild, and generally recede after 1-3 weeks of treatment. ${ }^{47}$ Gastrointestinal symptoms such as vomiting, abdominal pain, and diarrhea may occur. SLIT for pollens has been associated with the onset of eosinophilic esophagitis. ${ }^{48}$ A meta-analysis by Dhami et al ${ }^{49}$ in children and adults showed a risk for adverse events, more frequent with SCIT than with SLIT. Because SLIT is administered at home, instructions should be given regarding management of adverse reactions and when the administration of SLIT should be avoided (eg fever, asthma exacerbation, stomatitis, or eosinophilic esophagitis).

\section{SCIT Efficacy}

The results of the SCIT studies carried out in children with asthma are summarized in Table 1. Several meta-analyses reported the effectiveness of SCIT in improving asthma control.

A meta-analysis of double-blind randomized controlled trials on SCIT in asthmatics by Dhami et al ${ }^{49}$ selected 98 studies. They found that SCIT reduced short-term symptom and medication scores both in adults and children. Moreover, the analysis of individual allergens highlighted a benefit for AIT with HDM, grass pollen, and cat/dog dander, no benefit for mold and a possible effectiveness (not confirmed) for tree pollen. Finally, the metanalysis did not find conclusive data on long-term efficacy, that is the clinical improvement for at least 1 year after cessation of the therapy, and on cost-benefit impact. Another metaanalysis $^{50}$ reported a significant reduction in the asthma symptom scores and medication scores in the mitesensitized children and adults receiving SCIT compared with the control group. There were no significant differences between two groups in lung function and specific antibody levels of blood serum. In a systematic review that included a randomized controlled trial on SCIT efficacy in 
Table I SCIT Studies Carried Out in Patients with Asthma

\begin{tabular}{|c|c|c|c|c|c|}
\hline Author & Age (Years) & Participants (No) & Study Type & $\begin{array}{l}\text { Allergen } \\
\text { Extract }\end{array}$ & Main Efficacy Results \\
\hline $\begin{array}{l}\text { Dhami } \\
\text { et } \mathrm{al}^{49}\end{array}$ & Children and adults & $\begin{array}{l}98 \text { studies (SLIT and SCIT) on adults and } \\
\text { children with confirmed diagnosis of } \\
\text { allergic asthma }\end{array}$ & $\begin{array}{l}\text { Meta-analyses of } \\
\text { randomized } \\
\text { clinical trials }\end{array}$ & $\begin{array}{l}\text { Different (eg, } \\
\text { pollens, HDM, } \\
\text { animal dander, } \\
\text { cockroach, } \\
\text { and molds) }\end{array}$ & $\begin{array}{l}\text { Reductions in short-term symptom and } \\
\text { medication scores in allergic asthma } \\
\text { without conclusive data on longer-term } \\
\text { effectiveness and cost-effectiveness }\end{array}$ \\
\hline Lu et $\mathrm{al}^{50}$ & Children and adults & $\begin{array}{l}796 \text { patients with asthma alone or in } \\
\text { combination with other symptoms (AR, } \\
\text { conjunctivitis, dermatitis) }\end{array}$ & $\begin{array}{l}\text { Systematic } \\
\text { review and } \\
\text { metaanalysis }\end{array}$ & HDM & $\begin{array}{l}\text { Significant reduction in the asthma } \\
\text { symptom scores and medication scores } \\
\text { in the patient receiving SCIT compared } \\
\text { with the control group. No significant } \\
\text { differences between two groups in lung } \\
\text { function and specific antibody levels of } \\
\text { blood serum }\end{array}$ \\
\hline $\begin{array}{l}\text { Rice } \\
\text { et a }\left.\right|^{39}\end{array}$ & Children $\leq 18$ & $\begin{array}{l}40 \text { studies ( I SCIT trials, I I SLIT trials, } \\
8 \text { non-RCTs for SCIT safety, and } 4 \text { non- } \\
\text { RCTs for SLIT safety) }\end{array}$ & $\begin{array}{l}\text { Systematic } \\
\text { review }\end{array}$ & $\begin{array}{l}\text { Different (eg, } \\
\text { grass, HDM, } \\
\text { molds) }\end{array}$ & $\begin{array}{l}\text { SCIT diminished long-term medication } \\
\text { use and enhanced quality-of-life and } \\
\text { FEVI values }\end{array}$ \\
\hline $\begin{array}{l}\text { Di Bona } \\
\text { et } \mathrm{al}^{51}\end{array}$ & Children and adults & $\begin{array}{l}9 \text { studies and a total of } 168 \text { children and } \\
99 \text { adults }\end{array}$ & $\begin{array}{l}\text { Systematic } \\
\text { review }\end{array}$ & Molds & $\begin{array}{l}\text { Low strength evidence of efficacy of AIT } \\
\text { for the treatment of respiratory } \\
\text { allergies, although advocating the } \\
\text { necessity of higher-quality research with } \\
\text { an adequate sample size }\end{array}$ \\
\hline $\begin{array}{l}\text { Cools } \\
\text { et } \mathrm{al}^{52}\end{array}$ & Children and adults & $\begin{array}{l}\text { Asthmatic patients allergic to either } \\
\text { HDM (34) or to both HDM and grass } \\
\text { pollen (14) were re-evaluated in early } \\
\text { adulthood after mean cessation of AIT } \\
\text { for } 9.3 \pm 2.76 \text { years. The results were } \\
\text { compared to those of a control group } \\
\text { of asthmatic patients ( } 42 \text { ) with } \\
\text { comparable asthma features, who were } \\
\text { treated with appropriate antiasthmatic } \\
\text { drugs during childhood, but who never } \\
\text { received AIT }\end{array}$ & $\begin{array}{l}\text { Retrospective } \\
\text { study }\end{array}$ & $\begin{array}{l}\text { HDM or to } \\
\text { HDM and } \\
\text { grass pollen }\end{array}$ & $\begin{array}{l}\text { The } 2 \text { groups were then re-evaluated } \\
\text { about } 9 \text { years after the discontinuation, } \\
\text { the risk of frequent asthmatic symptoms } \\
\text { was } 3 \text {-times higher in the control group } \\
\text { than in the AIT-treated group. The } \\
\text { frequent use of antiasthmatic therapy } \\
\text { was also more pronounced in the } \\
\text { control group, although the difference } \\
\text { was not statistically significant. Lung- } \\
\text { function parameters were comparable } \\
\text { in both groups. }\end{array}$ \\
\hline $\begin{array}{l}\text { Stelmach } \\
\text { et al }\left.\right|^{53}\end{array}$ & $\begin{array}{l}\text { Children: Control } \\
\text { group: I2.2 }(\mathrm{SD}=2.9) \text {, } \\
\text { AIT3 group: II.7 } \\
(\mathrm{SD}=3.8) \text {, AIT5 group; } \\
13.9(\mathrm{SD}=3.7)\end{array}$ & $\begin{array}{l}30 \text { children with allergic asthma treated } \\
\text { for } 3 \text { years with HDM AIT, } 30 \text { treated } \\
\text { with a } 5 \text { years course of HDM AIT and } \\
\text { other } 30 \text { who refused HDM AIT }\end{array}$ & Prospective study & HDM & $\begin{array}{l}\text { Rate of asthma remission was significant } \\
\text { higher in both treated groups compared } \\
\text { with controls after } 3 \text { years } \\
\text { discontinuation therapy, without clinical } \\
\text { benefit continuing therapy for other } 2 \\
\text { years }\end{array}$ \\
\hline $\begin{array}{l}\text { Pifferi } \\
\text { et } \mathrm{al}^{54}\end{array}$ & $\begin{array}{l}\text { 6-14 (mean: 10.6I } \\
\pm 2.75 \mathrm{SD} \text { ) }\end{array}$ & $\begin{array}{l}\text { I5 children receiving AIT and I4 } \\
\text { controls (four drop-outs) with allergic } \\
\text { asthma }\end{array}$ & $\begin{array}{l}\text { Randomized } \\
\text { clinical trial }\end{array}$ & HDM & $\begin{array}{l}\text { Improves in asthmatic symptoms with } \\
\text { marked reduction in drug intake and } \\
\text { a significantly reduction in non-specific } \\
\text { bronchial hyper-responsiveness }\end{array}$ \\
\hline $\begin{array}{l}\text { Zielen } \\
\text { et } \mathrm{a}^{55}\end{array}$ & $6-17$ & $\begin{array}{l}65 \text { patients after reaching asthma } \\
\text { control with inhaled steroids during } \\
\text { a } 5 \text {-month baseline period, were } \\
\text { randomized for SCIT plus fluticasone } \\
\text { propionate (FP) or FP therapy alone for } \\
2 \text { year }\end{array}$ & $\begin{array}{l}\text { Randomized } \\
\text { clinical trial }\end{array}$ & HDM & $\begin{array}{l}\text { Decrease in fluticasone propionate } \\
\text { doses. A significant enhancement of the } \\
\text { morning PEF and increased levels of } \\
\operatorname{lgGI} \text { and } \operatorname{lgG} 4 \text { were also recorded }\end{array}$ \\
\hline
\end{tabular}

(Continued) 
Table I (Continued).

\begin{tabular}{|c|c|c|c|c|c|}
\hline Author & Age (Years) & Participants (No) & Study Type & $\begin{array}{l}\text { Allergen } \\
\text { Extract }\end{array}$ & Main Efficacy Results \\
\hline $\begin{array}{l}\text { Tsai } \\
\text { et } \mathrm{al}^{56}\end{array}$ & $\begin{array}{l}\text { Children: } \\
\text { Immunotherapy group } \\
\text { (mean age } 8.6 \pm 2.99 \\
\text { SD) } \\
\text { Control group (mean } \\
\text { age } 8.35 \pm 2.43 \mathrm{SD} \text { ) }\end{array}$ & $\begin{array}{l}40 \text { children with moderate-to-severe } \\
\text { allergic asthma were randomly assigned } \\
\text { to two groups: half of them received } \\
\text { HDM SCIT, while the other half were } \\
\text { not given immunotherapy }\end{array}$ & $\begin{array}{l}\text { Randomized } \\
\text { clinical trial }\end{array}$ & HDM & $\begin{array}{l}\text { Decrease in mean medication scores } \\
\text { after } 6 \text { months }\end{array}$ \\
\hline $\begin{array}{l}\text { Chen } \\
\text { et } \mathrm{al}^{57}\end{array}$ & $\begin{array}{l}5-14 \text { (mean age } 7.0 \\
\pm 1.9 \mathrm{SD})\end{array}$ & $\begin{array}{l}58 \text { asthmatic children ( } 35 \text { received } \\
\text { HDM AIT for I year, and the other } 23 \\
\text { children treated with inhaled } \\
\text { corticosteroids) }\end{array}$ & Clinical trial & HDM & $\begin{array}{l}\text { No of emergency visiting for asthma } \\
\text { attack in SCIT group was significantly } \\
\text { less than that in inhaled corticosteroids } \\
\text { group and that the pulmonary functions } \\
\text { and PEF percentage were significantly } \\
\text { improved in the SCIT group }\end{array}$ \\
\hline $\begin{array}{l}\text { Ibero } \\
\text { et } \mathrm{al}^{58}\end{array}$ & $8-16$ & $\begin{array}{l}30 \text { asthmatic children ( } 15 \text { were treated } \\
\text { with the modified allergen extract and } \\
\text { I5 received only pharmacologic } \\
\text { treatment) }\end{array}$ & $\begin{array}{l}\text { Randomized } \\
\text { controlled trial }\end{array}$ & HDM & $\begin{array}{l}\text { Significant improvement in skin } \\
\text { reactivity, symptom and medication } \\
\text { scores }\end{array}$ \\
\hline $\begin{array}{l}\text { Yukselen } \\
\text { et } \mathrm{al}^{59}\end{array}$ & $\begin{array}{l}\text { SCIT I0.9 } \pm 3.2 \text { SLIT } \\
9.2 \pm 3.4 \text { Placebo } 10.1 \\
\pm 2.7\end{array}$ & 30 children with rhinitis and asthma & $\begin{array}{l}\text { Randomized, } \\
\text { placebo- } \\
\text { controlled, } \\
\text { double-blind, } \\
\text { double-dummy } \\
\text { study }\end{array}$ & HDM & $\begin{array}{l}\text { SCIT significantly diminished symptom } \\
\text { and medication scores for rhinitis and } \\
\text { asthma }\end{array}$ \\
\hline $\begin{array}{l}\text { Alzakar } \\
\text { et } \mathrm{al}^{60}\end{array}$ & $\begin{array}{l}\text { Primary school } \\
\text { children }\end{array}$ & I 97 children with allergic asthma & $\begin{array}{l}\text { Single-blind, } \\
\text { drug-controlled } \\
\text { clinical trial }\end{array}$ & $\begin{array}{l}\text { Various } \\
\text { extracts } \\
\text { (trees, mite, } \\
\text { grass) }\end{array}$ & $\begin{array}{l}\text { At the follow-up after I year indicated } \\
\text { that the children treated with SCIT } \\
\text { show a marked reduction in combined } \\
\text { symptom and medication when } \\
\text { compared with children treated with } \\
\text { conventional therapy }\end{array}$ \\
\hline $\begin{array}{l}\text { Wahn } \\
\text { et } \mathrm{al}^{61}\end{array}$ & age $\geq 5$ & $\begin{array}{l}\text { 900I AIT patients and } 45,005 \text { matched } \\
\text { non-AIT control }\end{array}$ & $\begin{array}{l}\text { Retrospective } \\
\text { cohort analysis of } \\
\text { a German } \\
\text { longitudinal } \\
\text { prescription } \\
\text { database }\end{array}$ & Birch pollen & $\begin{array}{l}\text { Birch pollen AIT after to } 6 \text { years post- } \\
\text { treatment cessation significantly } \\
\text { reduced AR and asthma medication } \\
\text { intake, and significantly decreased risk } \\
\text { of new-onset asthma medication use } \\
\text { on-treatment }\end{array}$ \\
\hline $\begin{array}{l}\text { Moller } \\
\text { et } \mathrm{al}^{62}\end{array}$ & $6-14($ mean age $=10.7)$ & 205 children with AR & $\begin{array}{l}\text { Randomized, } \\
\text { placebo } \\
\text { controlled }\end{array}$ & $\begin{array}{l}\text { Grass and/or } \\
\text { birch pollen }\end{array}$ & $\begin{array}{l}\text { After } 3 \text { years, the SCIT-treated patients } \\
\text { developed significantly less asthma than } \\
\text { the control group }\end{array}$ \\
\hline
\end{tabular}

asthmatic children, Rice et $\mathrm{al}^{39}$ found evidence that SCIT diminished long-term medication use and enhanced quality-of-life and FEV1 values. Di Bona et $\mathrm{al}^{51}$ evaluated the efficacy of AIT on asthma in patients allergic to molds in a systematic review. They found low quality evidence for Alternaria and very low-quality evidence for Cladosporium. However, higher quality studies with larger sample of patients are needed to confirm the results.

In order to explore the long-term impact of SCIT on childhood asthma, a retrospective study was published by
Cools et al, ${ }^{52}$ in which asthmatics patients allergic to either HDM or to both HDM and grass pollen were treated with SCIT during childhood. The two groups were then reevaluated about 9 years after the discontinuation, the risk of frequent asthmatic symptoms was 3-times higher in the control group than in the AIT-treated group. The use of anti-asthmatic therapy was also more frequent in the control group than in the intervention group, although the difference was not statistically significant. Lung function was comparable in both groups. The authors concluded 
that AIT has long-term effects on asthmatic symptoms in young adults. Along the same line, Stelmach et $a l^{53}$ in 2012 performed a 3-year study of 90 asthmatic children who were sensitized only to HDM. Thirty patients completed 3 years of HDM SCIT, 30 completed 5 years of HDM SCIT, and 30 refused the treatment. The results showed efficacy in asthma remission in both treated groups compared to controls, and there was no further benefit in prolonging treatment after 3 years. Other studies compared HDM SCIT and inhaled corticosteroids therapy in allergic asthma to evaluate the steroid sparing effect of AIT. In a randomized clinical trial by Pifferi et $\mathrm{al}^{54}$ on HDM allergic asthmatic children, SCIT significantly improved asthmatic symptoms with marked reduction in drug intake and a significantly reduction in non-specific bronchial hyper-responsiveness. Another randomized study performed by Zielen et $\mathrm{al}^{55}$ on asthmatic children treated with HDM SCIT showed similar results with decrease in fluticasone propionate doses. Moreover, a significant enhancement of peak expiratory flow (PEF) and increased levels of IgG1 and IgG4 were reported.

Tsai et al, ${ }^{56}$ in a randomized clinical trial, enrolled 40 children with moderate-to-severe allergic asthma, reporting that specific immunotherapy was effective in reducing mean medication scores. Chen et $\mathrm{al}^{57}$ compared the efficacy of SCIT with a standardized Dermatophagoides pteronyssinus extract with inhaled corticosteroids for 1 year in asthmatic children. It was reported that the number of emergency visits for asthma attack in the SCIT group was significantly lower than in the inhaled corticosteroids group and that the pulmonary function, including PEF, significantly improved in the SCIT group.

In another study ${ }^{58}$ on asthmatic children treated with SCIT to HDM, the results showed significant improvement in skin reactivity, symptom, and medication scores.

Yukselen et al, ${ }^{59}$ in a 1 -year, randomized, placebocontrolled, double-blind, double-dummy study on 30 children, showed that SCIT significantly diminished symptom and medication scores for rhinitis and asthma.

In a single-blind, drug-controlled clinical trial performed by Alzakar et $\mathrm{al}^{60}$ on asthmatic children treated with SCIT with multiple allergens (trees, mite, grass) had a marked reduction in combined symptom-medication score when compared with long-term inhaled therapy.

Finally, Wahn et al, ${ }^{61}$ in a retrospective cohort analysis of a German longitudinal prescription database, show that birch pollen AIT after to 6 years post-treatment cessation significantly reduced AR and asthma medication intake, and significantly decreased risk of new-onset asthma medication use on-treatment.

AIT, including SCIT, plays a preventive role in the development of asthma in children with allergic rhinitis. The Preventive Allergy Treatment (PAT) study ${ }^{62}$ enrolled 205 children aged $5-13$ years (mean age $=10.7$ years) with oculorhinitis to grass and/or birch pollen randomized either to receive specific immunotherapy or to an open control group. Children were evaluated for the development of asthma after 3 years of SCIT. Actively treated patients developed significantly less asthma than the control group. At re-evaluation after 5 -years ${ }^{63}$ and 10 -years ${ }^{64}$ from the beginning of SCIT, long-term asthma prevention was found.

\section{SLIT Efficacy}

SLIT is effective in children with allergic rhinoconjunctivitis. ${ }^{8,49,65}$ Unfortunately, in most studies the parameters related to asthma were assessed only as a secondary outcome.

The results of the SLIT studies carried out in children with asthma are summarized in Table 2.

The effectiveness of SLIT for childhood asthma has been shown in several meta-analyses over time. A metaanalysis by Penagos et al ${ }^{66}$ included nine studies with 441 children (3-18 years of age), 232 and 209 of whom received SLIT and placebo, respectively. There was a significant reduction in asthma symptom scores and rescue medication. Olaguibel et al, ${ }^{67}$ in another metaanalysis on the efficacy of SLIT in 256 asthmatic children (129 treatment and 127 placebo recipients), showed the decrease in symptom and medication use. Liao et $\mathrm{al}^{68}$ evaluated the efficacy and safety of HDM SLIT in asthmatic children (230 patients treated with SLIT, and 224 with placebo/pharmacotherapy for 4 months to 3 years). They found a significant reduction in asthma symptoms score and an increase in sIgG4 levels greater than controls. In a $\mathrm{GA}^{2} \mathrm{LEN}$ meta-analysis ${ }^{69}$ nine trials involving 476 asthmatic children (243 mite SLIT vs 233 placebo) were included. The results showed a relevant reduction in symptom and medication scores, but a significant inter-study heterogeneity was found. A systematic review by Rice et $\mathrm{al}^{39}$ reported that SLIT improved drug consumption and increased FEV1. Larenas-Linneman et $\mathrm{al}^{47}$ systematically reviewed 29 clinical trials published from January 2009 through 2012 regarding SLIT in children. 
Table 2 SLIT Studies Carried Out in Patients with Asthma

\begin{tabular}{|c|c|c|c|c|c|}
\hline Author & $\begin{array}{l}\text { Age } \\
\text { (Years) }\end{array}$ & Participants $\left(\mathbf{N}^{\circ}\right)$ & Study Type & $\begin{array}{l}\text { Allergen } \\
\text { Extract }\end{array}$ & Main Efficacy Results \\
\hline $\begin{array}{l}\text { Penagos } \\
\text { et } \text { al }^{66}\end{array}$ & $3-18$ & $\begin{array}{l}9 \text { studies with } 44 \text { I children ( } 232 \text { and } 209 \text { of } \\
\text { whom received SLIT and placebo, } \\
\text { respectively) }\end{array}$ & Meta-analyses & $\begin{array}{l}\text { Perennial, } \\
\text { seasonal }\end{array}$ & $\begin{array}{l}\text { Significant reduction in asthma symptom } \\
\text { scores and rescue medication }\end{array}$ \\
\hline $\begin{array}{l}\text { Olaguibel } \\
\text { et } \mathrm{al}^{67}\end{array}$ & $\begin{array}{l}\leq 14 \\
\text { years-old }\end{array}$ & $\begin{array}{l}256 \text { children with rhinitis or asthma ( } 129 \\
\text { treatment and } 127 \text { placebo recipients) }\end{array}$ & Meta-analyses & $\begin{array}{l}\text { Perennial, } \\
\text { seasonal }\end{array}$ & $\begin{array}{l}\text { Decrease in symptom and medication } \\
\text { requirement in asthma }\end{array}$ \\
\hline Liao et $\mathrm{al}^{68}$ & $\begin{array}{l}\text { Children } \\
(<18 \\
\text { years of } \\
\text { age })\end{array}$ & $\begin{array}{l}454 \text { children ( } 230 \text { patients have used SLIT } \\
\text { treatment, and } 224 \text { were treated with } \\
\text { placebo/pharmacotherapy for } 4 \text { months to } 3 \\
\text { years) }\end{array}$ & Meta-analyses & HDM & $\begin{array}{l}\text { Significantly reduction in asthma symptoms } \\
\text { score and increased slgG } 4 \text { levels greater } \\
\text { than control in children ( }<18 \text { years of age) } \\
\text { with asthma }\end{array}$ \\
\hline $\begin{array}{l}\text { Compalati } \\
\text { et } \text { al }^{69}\end{array}$ & $\begin{array}{l}\text { Children } \\
\text { and } \\
\text { adults }\end{array}$ & $\begin{array}{l}476 \text { patients with asthma ( } 243 \text { SLIT vs } 233 \\
\text { placebo) }\end{array}$ & $\begin{array}{l}\text { GA2LEN meta- } \\
\text { analysis }\end{array}$ & HDM & $\begin{array}{l}\text { A relevant reduction in symptom scores but } \\
\text { a significant inter-study heterogeneity was } \\
\text { found }\end{array}$ \\
\hline $\begin{array}{l}\text { Larenas- } \\
\text { Linneman } \\
\text { et } \text { al }^{47}\end{array}$ & $\begin{array}{l}\text { Younger } \\
\text { than } 18 \\
\text { years }\end{array}$ & 454 asthmatic children & $\begin{array}{l}\text { Meta-analyses of } \\
\text { randomized } \\
\text { clinical trials }\end{array}$ & $\begin{array}{l}\text { Perennial, } \\
\text { seasonal }\end{array}$ & $\begin{array}{l}\text { Evidence is lacking for the precoseasonal } \\
\text { tablet and drop grass pollen SLIT efficacy in } \\
\text { seasonal asthma. For HDM SLIT in asthma, } \\
\text { there is high-quality evidence for medication } \\
\text { reduction while maintaining symptom } \\
\text { control. Nonspecific bronchial provocation } \\
\text { testing does not improve with grass pollen } \\
\text { and HDM SLIT }\end{array}$ \\
\hline $\begin{array}{l}\text { Stelmach } \\
\text { et } \mathrm{al}^{70}\end{array}$ & $6-18$ & $\begin{array}{l}60 \text { with rhinitis ( } 20 \text { patients had } \\
\text { concomitant asthma) }\end{array}$ & $\begin{array}{l}\text { Randomized, } \\
\text { double-blind } \\
\text { placebo- } \\
\text { controlled study }\end{array}$ & Grass pollen & $\begin{array}{l}\text { Decrease asthma symptoms and medication } \\
\text { score }\end{array}$ \\
\hline Majak et al ${ }^{71}$ & $6-17$ & 35 asthmatic children & $\begin{array}{l}\text { Double-blind, } \\
\text { placebo- } \\
\text { controlled study }\end{array}$ & Grass pollen & $\begin{array}{l}\text { High-dose ultrarush SLIT reduced the } \\
\text { severity of allergic symptoms in the first } 2 \\
\text { grass pollen seasons, but continuously } \\
\text { improved bronchial hyperreactivity in } \\
\text { children with asthma }\end{array}$ \\
\hline $\begin{array}{l}\text { Calamita } \\
\text { et } \mathrm{al}^{72}\end{array}$ & $\begin{array}{l}\text { Children } \\
\text { and } \\
\text { adults }\end{array}$ & I,706 patients with asthma & $\begin{array}{l}\text { Meta-analyses of } \\
\text { randomized } \\
\text { clinical trials }\end{array}$ & $\begin{array}{l}\text { Perennial, } \\
\text { seasonal }\end{array}$ & $\begin{array}{l}\text { Immunotherapy is beneficial for asthma } \\
\text { treatment, although the importance of the } \\
\text { effect is not very large }\end{array}$ \\
\hline $\begin{array}{l}\text { Dhami } \\
\text { et } \mathrm{al}^{49}\end{array}$ & $\begin{array}{l}\text { Children } \\
\text { and } \\
\text { adults }\end{array}$ & $\begin{array}{l}98 \text { studies (SLIT and SCIT) on adult and } \\
\text { children with confirmed diagnosis of allergic } \\
\text { asthma }\end{array}$ & $\begin{array}{l}\text { Meta-analyses of } \\
\text { randomized } \\
\text { clinical trials }\end{array}$ & $\begin{array}{l}\text { Different (eg, } \\
\text { pollens, HDM, } \\
\text { animal dander, } \\
\text { cockroach, and } \\
\text { molds) }\end{array}$ & $\begin{array}{l}\text { There were no significant effects on asthma } \\
\text { control, exacerbations, lung function, and } \\
\text { non-specific airway hyperreactivity }\end{array}$ \\
\hline $\begin{array}{l}\text { Normansell } \\
\text { et } \mathrm{al}^{73}\end{array}$ & $\begin{array}{l}\text { Children } \\
\text { and } \\
\text { adults }\end{array}$ & $\begin{array}{l}5,077 \text { patient ( } 18 \text { studies included only } \\
\text { adults, } 25 \text { included only children, and nine } \\
\text { recruited both or did not specify). Most of } \\
\text { the participant having mild or intermittent } \\
\text { asthma }\end{array}$ & $\begin{array}{l}\text { Cochrane } \\
\text { database } \\
\text { systematic } \\
\text { review }\end{array}$ & $\begin{array}{l}\text { Different (eg, } \\
\text { pollens, HDM, } \\
\text { animal dander, } \\
\text { cockroach, and } \\
\text { molds) }\end{array}$ & $\begin{array}{l}\text { Data on exacerbations and quality-of-life } \\
\text { and different unvalidated symptom and drug } \\
\text { scores are lacking }\end{array}$ \\
\hline $\begin{array}{l}\text { Di Rienzo } \\
\text { et } \mathrm{al}^{74}\end{array}$ & $\begin{array}{l}\text { Mean age } \\
8.5\end{array}$ & $\begin{array}{l}60 \text { children with allergic asthma/AR ( } 35 \\
\text { underwent a } 4-5 \text {-year course of SLIT with } \\
\text { standardized extract and } 25 \text { received only } \\
\text { drug therapy) }\end{array}$ & Prospective study & HDM & $\begin{array}{l}\text { In the SLIT group there was a significant } \\
\text { difference vs baseline for the presence of } \\
\text { asthma and the use of drugs asthma } \\
\text { medications. The mean PEF result was } \\
\text { significantly higher in the active group than } \\
\text { in the control group after } 10 \text { years }\end{array}$ \\
\hline
\end{tabular}

(Continued) 
Table 2 (Continued).

\begin{tabular}{|c|c|c|c|c|c|}
\hline Author & $\begin{array}{l}\text { Age } \\
\text { (Years) }\end{array}$ & Participants $\left(\mathbf{N}^{\circ}\right)$ & Study Type & $\begin{array}{l}\text { Allergen } \\
\text { Extract }\end{array}$ & Main Efficacy Results \\
\hline $\begin{array}{l}\text { Marogna } \\
\text { et al }{ }^{75}\end{array}$ & $\begin{array}{l}\text { Mean age } \\
\text { of } 22.2 \\
\pm 5.2\end{array}$ & 59 patients and 12 controls & $\begin{array}{l}\text { Prospective open } \\
\text { controlled study }\end{array}$ & HDM & $\begin{array}{l}\text { In the patients receiving SLIT for } 3 \text { years, the } \\
\text { clinical benefit persisted for } 7 \text { years. In those } \\
\text { receiving immunotherapy for } 4 \text { or } 5 \text { years, } \\
\text { the clinical benefit persisted for } 8 \text { years }\end{array}$ \\
\hline $\begin{array}{l}\text { Tahamiler } \\
\text { et } \mathrm{al}^{76}\end{array}$ & $\begin{array}{l}\text { Mean age } \\
27.9 \mid \\
\pm 9.73 \\
\text { range } \\
|2-5| \\
\text { years }\end{array}$ & 137 patients & $\begin{array}{l}\text { Randomized } \\
\text { controlled Trial }\end{array}$ & HDM & $\begin{array}{l}\text { There is a greater improvement in the } 3 \\
\text { years of sublingual immunotherapy } \\
\text { compared to the } 2 \text { years of sublingual } \\
\text { immunotherapy }\end{array}$ \\
\hline $\begin{array}{l}\text { Ozdemir } \\
\text { et } \mathrm{al}^{77}\end{array}$ & $4-16$ & $\begin{array}{l}\text { Children with asthma SLIT }+ \\
\text { pharmacotherapy }(n=62) \text { or } \\
\text { pharmacotherapy alone }(n=28)\end{array}$ & $\begin{array}{l}\text { Controlled } \\
\text { clinical trial }\end{array}$ & HDM & $\begin{array}{l}\text { Decrease the duration and dose of inhaled } \\
\text { corticosteroid }\end{array}$ \\
\hline Eifan et $\mathrm{al}^{78}$ & $5-10$ & $\begin{array}{l}48 \text { patients SLIT }(n=16) \text {, SCIT }(n=16) \text {, or } \\
\text { pharmacotherapy alone }(n=16)\end{array}$ & $\begin{array}{l}\text { Open } \\
\text { randomized } \\
\text { controlled trial }\end{array}$ & HDM & $\begin{array}{l}\text { Both SLIT and SCIT demonstrated clinical } \\
\text { improvement compared with } \\
\text { pharmacotherapy in asthma/rhinitis children } \\
\text { sensitized to HDM }\end{array}$ \\
\hline $\begin{array}{l}\text { Novembre } \\
\text { et } \mathrm{al}^{79}\end{array}$ & $\begin{array}{l}5-14 \\
(\text { mean } \\
\text { age }=7.7 \\
\text { years })\end{array}$ & II3 children & $\begin{array}{l}\text { Open } \\
\text { randomized } \\
\text { study }\end{array}$ & Grass pollen & $\begin{array}{l}\text { Three years of coseasonal SLIT improves } \\
\text { seasonal allergic rhinitis symptoms and } \\
\text { reduces the development of seasonal } \\
\text { asthma in children with hay fever }\end{array}$ \\
\hline $\begin{array}{l}\text { Valovirta } \\
\text { et } \mathrm{al}^{80}\end{array}$ & $5-12$ & 812 children with seasonal allergic rhinitis & $\begin{array}{l}\text { Double-blind, } \\
\text { placebo- } \\
\text { controlled study }\end{array}$ & Seasonal & $\begin{array}{l}\text { Improve clinical effect on rhinoconjunctivitis } \\
\text { and a decreased risk of experiencing asthma } \\
\text { symptoms and using asthma drugs }\end{array}$ \\
\hline $\begin{array}{l}\text { Devillier } \\
\text { et al }\end{array}$ & Over 5 & $\begin{array}{l}\text { I,099 children with AR having received at } \\
\text { least two prescriptions of grass pollen SLIT } \\
\text { tablets per course of treatment over at least } \\
2 \text { consecutive years and } 27,475 \text { control } \\
\text { patients with moderate-to-severe disease }\end{array}$ & $\begin{array}{l}\text { Retrospective } \\
\text { real-world } \\
\text { analysis }\end{array}$ & Grass pollen & $\begin{array}{l}\text { During the follow-up, I.8\% vs } 5.3 \% \text { of } \\
\text { patients started asthma treatment in the } \\
\text { SLIT and control groups, respectively. In } \\
\text { addition, the relative risk of drugs dispensing } \\
\text { for new asthma was less in the SLIT group. } \\
\text { SLIT group was also associated with } \\
\text { a slower progression of asthma therapy } \\
\text { delivery during follow-up period, relating to } \\
\text { the control group }\end{array}$ \\
\hline $\begin{array}{l}\text { Zielen } \\
\text { et } \mathrm{al}^{82}\end{array}$ & Over 5 & 2,85I SLIT and 7I,275 control patients & $\begin{array}{l}\text { Retrospective } \\
\text { analysis of } \\
\text { a German } \\
\text { longitudinal } \\
\text { prescription } \\
\text { database }\end{array}$ & Grass pollen & $\begin{array}{l}\text { Treatment of AR patients with grass pollen } \\
\text { SLIT tablets was associated with slower AR } \\
\text { progression, less frequent asthma onset, and } \\
\text { slower asthma progression }\end{array}$ \\
\hline
\end{tabular}

Evidence for precoseasonal tablet and drop grass pollen SLIT efficacy in asthma was lacking. There was evidence that mite SLIT reduced consumption of anti-asthmatic medication. Non-specific bronchial provocation testing did not improve with grass pollen and HDM SLIT.

Other randomized studies ${ }^{70,71}$ concluded that immunotherapy with the grass tablet reduced asthma symptoms in a pediatric population, irrespective of SLIT given continuously along the year or (pre)-co-seasonally. In metaanalyses involving both adults and children are found more conflicting results. Twenty-five randomized-controlled clinical trials on SLIT in 1,706 adults and children with asthma were included in the meta-analysis by Calamita et al. ${ }^{72}$ It was found that immunotherapy was of benefit for asthma treatment, although the importance of the effect was not very large. In contrast, in the meta-analysis by Dhami et al, ${ }^{49}$ 
which included 98 studies in children and adults with asthma, SLIT did not produce significant effects on asthma control, exacerbations, lung function, and non-specific airway hyperreactivity. Normansell et al, ${ }^{73}$ in a Cochrane database systematic review on SLIT in asthma, assessed 52 studies with 5,077 patients (18 studies included only adults, 25 included only children, and nine recruited both or did not specify). The authors found inconclusive results due to the lack of data on exacerbations and quality-of-life, and the use of different unvalidated symptom and drug scores.

In a prospective study ${ }^{74}$ in children with HDM allergic asthma/AR, the long-term effects of SLIT were evaluated. The patients were divided into two groups: one underwent a 4- to 5-year course of SLIT with standardized extract, and the other received only medication therapy. In the SLIT group there was a significant difference vs baseline for the presence of asthma and the use of drugs asthma medications. The mean PEF result was significantly higher in the active group than in the control group after 10 years. The long-lasting effects of SLIT have also been shown by several studies. ${ }^{75-77}$

In a single-center, prospective, randomized, controlled, open labeled, ${ }^{78}$ three parallel group trial, 48 patients mono-sensitized to HDM were randomized to receive either SLIT $(n=16)$, SCIT $(n=16)$, or pharmacotherapy alone $(n=16)$. Both SLIT and SCIT demonstrated clinical improvement compared with pharmacotherapy in asthma/ rhinitis children sensitized to HDM.

Onset of asthma in children with seasonal rhinoconjunctivitis was prevented by grass SLIT drops. ${ }^{79}$ Furthermore, a large double-blind, placebo-controlled trial with grass tablets found that they improved rhinoconjunctivitis and reduced the risk of developing asthma. ${ }^{80}$ Moreover, these benefits were maintained after cessation of SLIT.

A potential preventive role of immunotherapy on development of asthma was also suggested by Devillier et $\mathrm{al}^{81}$ in a retrospective database study. They evaluated 1,099 children with AR who received at least two prescriptions of grass pollen SLIT tablets per course of treatment over at least 2 consecutive years, and 27,475 control patients with moderate-to-severe disease, defined as at least two prescriptions dispensed of nasal corticosteroids during two subsequent pollen seasons. During the followup, $1.8 \%$ vs $5.3 \%$ of patients started asthma treatment in the SLIT and control groups, respectively. In addition, the relative risk of drugs dispensing for new asthma was less
Table 3 Key Messages

I. Allergen immunotherapy is the only treatment that can modify the immune response upon exposure to aeroallergens.

2. Short- and long-term AIT benefits in the asthma treatment are documented.

3. No consensus exists on the optimal endpoints of asthma.

4. Increasing safety and efficiency is the main goal of research for novel immunotherapy development and improvement of treatment in asthma.

in the SLIT group. There was also a slower progression of asthma therapy delivery during the follow-up period in the SLIT group than in the control group.

In another retrospective analysis of a German longitudinal prescription database, ${ }^{82}$ treatment of AR patients with grass pollen SLIT tablets was associated with slower AR progression, less frequent asthma onset, and slower asthma progression.

\section{Conclusion}

Currently, allergen immunotherapy is the only treatment that can modify the immune response upon exposure to aeroallergens (Table 3). There is evidence that AIT not only improves rhinoconjunctival symptoms, but also has short- and long-term beneficial effects in asthma treatment. The disease modification properties consist of a reduction in symptom severity, less drug consumption, and a longterm therapeutic effect. However, there are controversial recommendations on AIT in asthma guidelines. An explanation may be that, due to the heterogeneity of allergen extract, it is challenging to combine results of studies that use different AIT products in metanalyses. It would be advisable to evaluate every allergen extract separately in order to assess the safety and efficacy profile of each one. Moreover, no consensus exists on the optimal endpoints of AIT in asthmatics. Large trials using standardized and validated tools to evaluate key outcomes in asthma are warranted.

\section{Abbreviations}

AR, allergic rhinitis; AIT, allergen-specific immunotherapy; SCIT, subcutaneous immunotherapy; SLIT, sublingual immunotherapy; GINA, Global Initiative for Asthma; $\mathrm{HDM}$, house dust mite; $\mathrm{FEV}_{1}$, forced expiratory volume in the 1st second; Treg, T-regulatory cells; nTreg, natural 
regulatory T-cells; iTreg, induced regulatory T-cells; $\mathrm{PEF}$, peak expiratory flow.

\section{Funding}

This research received no external funding.

\section{Disclosure}

The authors declare no conflict of interest.

\section{References}

1. Global Initiative for Asthma. Global initiative for asthma: global strategy for asthma management and prevention, 2020; 2020. Available from: https://ginasthma.org/gina-reports/. Accessed August 7, 2020.

2. Accordini S, Corsico AG, Calciano L, et al. The impact of asthma, chronic bronchitis and allergic rhinitis on all-cause hospitalizations and limitations in daily activities: a population-based observational study. BMC Pulm Med. 2015;15:10. doi:10.1186/s12890-015-0008-0

3. Kuruvilla ME, Lee FE, Lee GB. Understanding asthma phenotypes, endotypes, and mechanisms of disease. Clin Rev Allergy Immunol. 2019;56(2):219-233. doi:10.1007/s12016-018-8712-1

4. Mastrorilli C, Posa D, Cipriani F, Caffarelli C. Asthma and allergic rhinitis in childhood: what's new. Pediatr Allergy Immunol. 2016;27 (8):795-803. doi:10.1111/pai.12681

5. Chipps BE, Bacharier LB, Murphy KR, et al. The asthma controller step-down yardstick. Ann Allergy Asthma Immunol. 2019;122 (3):241-262.e4. doi:10.1016/j.anai.2018.12.004

6. Cipriani F, Mastrorilli C, Tripodi S, et al. Diagnostic relevance of IgE sensitization profiles to eight recombinant Phleum pratense molecules. Allergy. 2018;73(3):673-682. doi:10.1111/all.13338

7. Caffarelli C, Garrubba M, Greco C, Mastrorilli C, Povesi Dascola C. Asthma and food allergy in children: is there a connection or interaction? Front Pediatr. 2016;4:34. doi:10.3389/fped.2016.00034

8. Roberts G, Pfaar O, Akdis CA, et al. EAACI guidelines on allergen immunotherapy: allergic rhinoconjunctivitis. Allergy. 2018;73 (4):765-798.

9. Alvaro-Lozano M, Akdis CA, Akdis M, et al. EAACI allergen immunotherapy user's guide. Pediatr Allergy Immunol. 2020;31 (Suppl 25):1-101. doi:10.1111/pai.13189

10. Di Rienzo V, Cadario G, Grieco T, et al. Sublingual immunotherapy in mite-sensitized children with atopic dermatitis: a randomized, open, parallel-group study. Ann Allergy Asthma Immunol. 2014;113 (6):671-673. doi:10.1016/j.anai.2014.09.009

11. Nurmatov U, Dhami S, Arasi S. Allergen immunotherapy for IgE-mediated food allergy: a systematic review and meta-analysis. Allergy. 2017;72(8):1133-1147. doi:10.1111/all.13124

12. Noon L, Cantar BO. Prophylactic inoculation against hay fever. Lancet. 1911;1:1572-1573.

13. Scadding GK, Brostoff J. Low dose sublingual therapy in patients with allergic rhinitis due to house dust mite. Clin Exp Allergy. 1986;16(5):483-491. doi:10.1111/j.1365-2222.1986.tb01983.x

14. Warner JO. Low dose sublingual therapy in patients with allergic rhinitis due to house dust mite. Clin Allergy. 1986;16(5):387-388. doi:10.1111/j.1365-2222.1986.tb01973.x

15. Okamoto Y, Fujieda S, Okano M, Hida H, Kakudo S, Masuyama K. Efficacy of house dust mite sublingual tablet in the treatment of allergic rhinoconjunctivitis: a randomized trial in a pediatric population. Pediatr Allergy Immunol. 2019;30(1):66-73. doi:10.1111/pai.12984

16. EMA European Medicine Agency. Committee for medicinal products for human use (CHMP). Guideline on allergen products: production and quality issues. EMEA/CHMP/BWP/304831/2007; 2008. Available from: https://www.ema.europa.eu/en/allergen-productsproduction-quality-issues. Accessed August 28, 2020.
17. Jacobsen L, Wahn U, Bilo MB. Allergen-specific immunotherapy provides immediate, long-term and preventive clinical effects in children and adults: the effects of immunotherapy can be categorised by level of benefit -the centenary of allergen specific subcutaneous immunotherapy. Clin Transl Allergy. 2012;2:8. doi:10.1186/2045-7022-2-8

18. Casset A, Mari A, Purohit A, et al. Varying allergen composition and content affects the in vivo allergenic activity of commercial Dermatophagoides pteronyssinus extracts. Int Arch Allergy Immunol. 2012;159(3):253-262. doi:10.1159/000337654

19. Moreno Benítez F, Espinazo Romeu M, Letrán Camacho A, Mas S, García-Cózar FJ, Tabar AI. Variation in allergen content in sublingual allergen immunotherapy with house dust mites. Allergy. 2015;70 (11):1413-1420. doi:10.1111/all.12694

20. Pfaar O, Agache I, de Blay F, et al. Perspectives in allergen immunotherapy: 2019 and beyond. Allergy. 2019;74(Suppl 108):3-25. doi:10.1111/all.14077

21. Novak N, Bieber T, Allam JP. Immunological mechanisms of sublingual allergen-specific immunotherapy. Allergy. 2011;66(6):733-739. doi:10.1111/j.1398-9995.2010.02535.x

22. Moingeon P. Update on immune mechanisms associated with sublingual immunotherapy: practical implications for the clinician. J Allergy Clin Immunol Pract. 2013;1(3):228-241. doi:10.1016/j.jaip. 2013.03.013

23. Akdis CA, Akdis M. Mechanisms of allergen-specific immunotherapy and immune tolerance to allergens. World Allergy Organ J. 2015;8(1):1-12. doi:10.1186/s40413-015-0063-2

24. Eberlein-König B, Ullmann S, Thomas P, Przybilla B. Tryptase and histamine release due to a sting challenge in bee venom allergic patients treated successfully or unsuccessfully with hyposensitization. Clin Exp Allergy. 1995;25(8):704-712.

25. Shamji MH, Layhadi JA, Scadding GW, et al. Basophil expression of diamine oxidase: a novel biomarker of allergen immunotherapy response. J Allergy Clin Immunol. 2015;135(4):913-921. doi:10.10 16/j.jaci.2014.09.049

26. Novak N, Mete N, Bussmann C, et al. Early suppression of basophil activation during allergen-specific immunotherapy by histamine receptor 2. J Allergy Clin Immunol. 2012;130(5):1153-1158. doi:10. 1016/j.jaci.2012.04.039

27. He YT, Zhou Y, Shao Q, et al. Immunoregulatory effects of subcutaneous immunotherapy on lymphocyte subgroups and cytokines in children with asthma. J Immunol Res. 2019;2019:7024905. doi:10.1155/2019/7024905

28. Caffarelli C, Cangemi J, Mastrorilli C, Giannetti A, Ricci G. Allergen-specific immunotherapy for inhalant allergens in children. Curr Pediatr Rev. 2020;16(2):129-139. doi:10.2174/1573396315 666191021104003

29. Cuppari C, Leonardi S, Manti S, et al. Allergen immunotherapy, routes of administration and cytokine networks: an update. Immunotherapy. 2014;6(6):775-786. doi:10.2217/imt.14.47

30. Cox L, Nelson H, Lockey R, et al. Allergen immunotherapy: a practice parameter third update. $J$ Allergy Clin Immunol. 2011;127(1 Suppl):S1-S55. doi:10.1016/j.jaci.2010.09.034

31. Calderón MA, Cox L, Casale TB, Moingeon P, Demoly P. Multipleallergen and single-allergen immunotherapy strategies in polysensitized patients: looking at the published evidence. J Allergy Clin Immunol. 2012;129(4):929-934. doi:10.1016/j.jaci.2011.11.019

32. Calderón MA, Simons FE, Malling HJ, Lockey RF, Moingeon P, Demoly P. Sublingual allergen immunotherapy: mode of action and its relationship with the safety profile. Allergy. 2012;67(3):302-311. doi:10.1111/j.1398-9995.2011.02761.x

33. Pitsios C, Tsoumani M, Bilò MB, et al. Contraindications to immunotherapy: a global approach. Clin Transl Allergy. 2019;9:45. doi:10.1186/s13601-019-0285-4

34. Jutel M, Agache I, Bonin S, et al. International consensus on allergy immunotherapy. J Allergy Clin Immunol. 2015;136(3):556-568. doi:10.1016/j.jaci.2015.04.047 
35. Temino VM, Wu P, Konig J, Fahrenholz JM. Safety of multiple aeroallergen rush immunotherapy using a modified schedule. Allergy Asthma Proc. 2013;34(3):255-260. doi:10.2500/ aap.2013.34.3651

36. Aaronson DW, Gandhi TK. Incorrect allergy injections: allergists' experiences and recommendations for prevention. J Allergy Clin Immunol. 2004;113(6):1117-1121. doi:10.1016/j.jaci.2004.01.756

37. Cox L, Larenas-Linnemann D, Lockey RF, Passalacqua G. Speaking the same language: the World Allergy Organization subcutaneous immunotherapy systemic reaction grading system. J Allergy Clin Immunol. 2010;125(3):569-74, 574. doi:10.1016/j.jaci.2009.10.060

38. Petalas K, Durham SR. Allergen immunotherapy for allergic rhinitis. Rhinology. 2013;51(2):99-110.

39. Rice JL, Diette GB, Suarez-Cuervo C, et al. Allergen-specific immunotherapy in the treatment of pediatric asthma: a systematic review. Pediatrics. 2018;141(5):e20173833. doi:10.1542/peds.2017-3833

40. Lee JH, Kim SC, Choi H, et al. A retrospective study of clinical response predictors in subcutaneous allergen immunotherapy with house dust mites for allergic rhinitis. Allergy Asthma Immunol Res. 2018;10(1):18-24. doi:10.4168/aair.2018.10.1.18

41. Schiappoli M, Ridolo E, Senna G, et al. A prospective Italian survey on the safety of subcutaneous immunotherapy for respiratory allergy. Clin Exp Allergy. 2009;39(10):1569-1574. doi:10.1111/j.13652222.2009.03286.x

42. Dunsky EH, Goldstein MF, Dvorin DJ, Belecanech GA. Anaphylaxis to sublingual immunotherapy. Allergy. 2006;61(10):1235. doi:10. 1111/j.1398-9995.2006.01137.x

43. Vovolis V, Kalogiros L, Mitsias D, Sifnaios E. Severe repeated anaphylactic reactions to sublingual immunotherapy. Allergol Immunopathol (Madr). 2013;41(4):279-281. doi:10.1016/j.aller.2012.05.012

44. Nelson HS. Multiallergen immunotherapy for allergic rhinitis and asthma. J Allergy Clin Immunol. 2009;123(4):763-769.

45. Cox LS, Larenas Linnemann D, Nolte H, Weldon D, Finegold I, Nelson HS. Sublingual immunotherapy: a comprehensive review. $J$ Allergy Clin Immunol. 2006;117(5):1021-1035. doi:10.1016/j. jaci.2006.02.040

46. Mastrorilli C, Cardinale F, Giannetti A, Caffarelli C. Pollen-food allergy syndrome: a not so rare disease in childhood. Medicina (Kaunas). 2019;55(10):641. doi:10.3390/medicina55100641

47. Larenas-Linnemann D, Blaiss M, Van Bever HP, Compalati E, Baena-Cagnani CE. Pediatric sublingual immunotherapy efficacy: evidence analysis, 2009-2012. Ann Allergy Asthma Immunol. 2013;110(6):402-415.e9. doi:10.1016/j.anai.2013.02.017

48. Miehlke S, Alpan O, Schröder S, Straumann A. Induction of eosinophilic esophagitis by sublingual pollen immunotherapy. Case Rep Gastroenterol. 2013;7(3):363-368. doi:10.1159/000355161

49. Dhami S, Nurmatov U, Arasi S, et al. Allergen immunotherapy for allergic rhinoconjunctivitis: a systematic review and meta-analysis. Allergy. 2017;72(11):1597-1631.

50. Lu Y, Xu L, Xia M, Li Y, Cao L. The efficacy and safety of subcutaneous immunotherapy in mite-sensitized subjects with asthma: A meta-analysis. Respir Care. 2015;60(2):269-278. doi: $10.4187 /$ respcare.03399

51. Di Bona D, Frisenda F, Albanesi M, Di Lorenzo G, Caiaffa MF, Macchia L. Efficacy and safety of allergen immunotherapy in patients with allergy to molds: a systematic review. Clin Exp Allergy. 2018;48 (11):1391-1401. doi:10.1111/cea.13242

52. Cools M, Van Bever HP, Weyler JJ, et al. Long-term effects of specific immunotherapy, administered during childhood, in asthmatic patients allergic to either house-dust mite or to both house-dust mite and grass pollen. Allergy. 2000;55(1):69-73. doi:10.1034/j.13989995.2000.00191.x

53. Stelmach I, Sobocińska A, Majak P, Smejda K, Jerzyńska J, Stelmach W. Comparison of the long-term efficacy of 3- and 5-year house dust mite allergen immunotherapy. Ann Allergy Asthma Immunol. 2012;109 (4):274-278. doi:10.1016/j.anai.2012.07.015
54. Pifferi M, Baldini G, Marrazzini G, et al. Benefits of immunotherapy with a standardized Dermatophagoides pteronyssinus extract in asthmatic children: a three-year prospective study. Allergy. 2002;57 (9):785-790. doi:10.1034/j.1398-9995.2002.23498.x

55. Zielen S, Kardos P, Madonini E. Steroid-sparing effects with allergen-specific immunotherapy in children with asthma: a randomized controlled trial. J Allergy Clin Immunol. 2010;126 (5):942-949. doi:10.1016/j.jaci.2010.06.002

56. Tsai TC, Lu JH, Chen SJ, et al. Clinical efficacy of house dust mite-specific immunotherapy in asthmatic children. Pediatr Neonatol. 2010;51(1):14-18. doi:10.1016/S1875-9572(10)60004-6

57. Chen ZG, Li M, Chen YF, et al. Effects of dermatophagoides pteronyssinus allergen-specific immunotherapy on the serum interleukin-13 and pulmonary functions in asthmatic children. Chin Med J (Engl). 2009;122(10):1157-1161.

58. Ibero M, Castillo MJ. Significant improvement of specific bronchial hyperreactivity in asthmatic children after 4 months of treatment with a modified extract of Dermatophagoides pteronyssinus. J Investig Allergol Clin Immunol. 2006;16(3):194-202.

59. Yukselen A, Kendirli SG, Yilmaz M, Altintas DU, Karakoc GB. Effect of one-year subcutaneous and sublingual immunotherapy on clinical and laboratory parameters in children with rhinitis and asthma: a randomized, placebo-controlled, double-blind, double-dummy study. Int Arch Allergy Immunol. 2012;157(3):288-298. doi:10.1159/000327566

60. Alzakar RH, Alsamarai AM. Efficacy of immunotherapy for treatment of allergic asthma in children. Allergy Asthma Proc. 2010;31 (4):324-330. doi:10.2500/aap.2010.31.3353

61. Wahn U, Bachert C, Heinrich J, Richter H, Zielen S. Real-world benefits of allergen immunotherapy for birch pollen-associated allergic rhinitis and asthma. Allergy. 2019;74(3):594-604. doi:10.1111/ all.13598

62. Möller C, Dreborg S, Ferdousi HA, et al. Pollen immunotherapy reduces the development of asthma in children with seasonal rhinoconjunctivitis (the PAT-Study). J Allergy Clin Immunol. 2002;109 (2):251-256. doi:10.1067/mai.2002.121317

63. Niggemann B, Jacobsen L, Dreborg S, et al. Five-year follow-up on the PAT study: specific immunotherapy and long-term prevention of asthma in children. Allergy. 2006;61(7):855-859. doi:10.1111/j.13989995.2006.01068.x

64. Jacobsen L, Niggemann B, Dreborg S, et al. Specific immunotherapy has long-term preventive effect of seasonal and perennial asthma: 10-year follow-up on the PAT study. Allergy. 2007;62(8):943-948. doi:10.1111/j.1398-9995.2007.01451.x

65. Lin SY, Azar A, Suarez-Cuervo C, et al. Role of sublingual immunotherapy in the treatment of asthma: an updated systematic review. Int Forum Allergy Rhinol. 2018;8(9):982-992.

66. Penagos M, Passalacqua G, Compalati E, et al. Meta-analysis of the efficacy of sublingual immunotherapy in the treatment of allergic asthma in pediatric patients, 3 to 18 years of age. Chest. 2008;133 (3):599-609. doi:10.1378/chest.06-1425

67. Olaguíbel JM, Álvarez Puebla MJ. Efficacy of sublingual allergen vaccination for respiratory allergy in children. Conclusions from one meta-analysis. J Investig Allergol Clin Immunol. 2005;15(1):9-16.

68. Liao W, Hu Q, Shen LL, et al. Sublingual immunotherapy for asthmatic children sensitized to house dust mite: A meta-analysis. Medicine (Baltimore). 2015;94(24):e701. doi:10.1097/MD.00000 00000000701

69. Compalati E, Passalacqua G, Bonini M, Canonica GW. The efficacy of sublingual immunotherapy for house dust mites respiratory allergy: results of a GA2LEN meta-analysis. Allergy. 2009;64 (11):1570-1579. doi:10.1111/j.1398-9995.2009.02129.x

70. Stelmach I, Kaluzińska-Parzyszek I, Jerzynska J, Stelmach P, Stelmach W, Majak P. Comparative effect of pre-coseasonal and continuous grass sublingual immunotherapy in children. Allergy Eur $J$ Allergy Clin Immunol. 2012;67(3):312-320. doi:10.1111/j.13989995.2011.02758.x 
71. Majak P, Kaczmarek-Woźniak J, Brzozowska A, BobrowskaKorzeniowska M, Jerzynska J, Stelmach I. One-year follow-up of clinical and inflammatory parameters in children allergic to grass pollen receiving high-dose ultrarush sublingual immunotherapy. J Investig Allergol Clin Immunol. 2010;20(7):602-606.

72. Calamita Z, Saconato H, Pelá AB, Atallah AN. Efficacy of sublingual immunotherapy in asthma: systematic review of randomized-clinical trials using the Cochrane Collaboration method. Allergy. 2006;61 (10):1162-1172. doi:10.1111/j.1398-9995.2006.01205.x

73. Normansell R, Kew KM, Bridgman AL. Sublingual immunotherapy for asthma. Cochrane Database Syst Rev. 2015;28(8):CD011293.s.

74. Di Rienzo V, Marcucci F, Puccinelli P, et al. Long-lasting effect of sublingual immunotherapy in children with asthma due to house dust mite: A 10-year prospective study. Clin Exp Allergy. 2003;33 (2):206-210. doi:10.1046/j.1365-2222.2003.01587.x

75. Marogna M, Spadolini I, Massolo A, Canonica GW, Passalacqua G. Long-lasting effects of sublingual immunotherapy according to its duration: a 15-year prospective study. J Allergy Clin Immunol. 2010;126(5):969-975.

76. Tahamiler R, Saritzali G, Canakcioglu S, et al. Long-term efficacy of sublingual immunotherapy in patients with perennial rhinitis. Laryngoscope. 2007;117(6):965-969. doi:10.1097/MLG.0b013e3 $1804 \mathrm{f} 8141$

77. Ozdemir C, Yazi D, Gocmen I, et al. Efficacy of long-term sublingual immunotherapy as an adjunct to pharmacotherapy in house dust mite-allergic children with asthma. Pediatr Allergy Immunol. 2007;18(6):508-515. doi:10.1111/j.1399-3038.2007.00549.x
78. Eifan AO, Akkoc T, Yildiz A, et al. Clinical efficacy and immunological mechanisms of sublingual and subcutaneous immunotherapy in asthmatic/rhinitis children sensitized to house dust mite: an open randomized controlled trial. Clin Exp Allergy. 2010;40(6):922-932. doi:10.1111/j.1365-2222.2009.03448.x

79. Novembre E, Galli E, Landi F, et al. Coseasonal sublingual immunotherapy reduces the development of asthma in children with allergic rhinoconjunctivitis. $J$ Allergy Clin Immunol. 2004;114 (4):851-857. doi:10.1016/j.jaci.2004.07.012

80. Valovirta E, Petersen TH, Piotrowska T, et al. Results from the 5-year SQ grass sublingual immunotherapy tablet asthma prevention (GAP) trial in children with grass pollen allergy. J Allergy Clin Immunol. 2018;141(2):529-538.e13. doi:10.1016/j.jaci.2017.06.014

81. Devillier P, Molimard M, Ansolabehere X, et al. Immunotherapy with grass pollen tablets reduces medication dispensing for allergic rhinitis and asthma: a retrospective database study in France. Allergy. 2019;74(7):1317-1326.

82. Zielen S, Devillier P, Heinrich J, Richter H, Wahn U. Sublingual immunotherapy provides long-term relief in allergic rhinitis and reduces the risk of asthma: a retrospective, real-world database analysis. Allergy. 2018;73(1):165-177. doi:10.1111/all.13213

\section{Publish your work in this journal}

The Journal of Asthma and Allergy is an international, peer-reviewed open-access journal publishing original research, reports, editorials and commentaries on the following topics: Asthma; Pulmonary physiology; Asthma related clinical health; Clinical immunology and the immunological basis of disease; Pharmacological interventions and new therapies. The manuscript management system is completely online and includes a very quick and fair peer-review system, which is all easy to use. Visit http://www.dovepress.com/testimonials.php to read real quotes from published authors. 